\title{
KUALITAS PELAYANAN PUBLIK MELALUI APLIKASI SISTEM ADMINISTRASI KEPENDUDUKAN BERBASIS TEKNOLOGI INFORMASI (SAKTI) DI KELURAHAN SEMAMPIR
}

\author{
*Djoko Susanto ${ }^{1)}$, Indira Puspita Kristiawan ${ }^{2)}$, Teguh Pramono ${ }^{3)}$ \\ ${ }^{1,2,3)}$ Administrasi Publik, Fakultas Ilmu Sosial dan Ilmu Politik, Universitas Kediri, Indonesia \\ *Email Korespondensi : puspitaindria7@gmail.com
}

\begin{abstract}
Abstrak
Teknologi Informasi bisa di lakukan dengan berbagai cara, salah satunya yaitu melalui internet yang bisa digunakan dimanapun dan kapanpun menggunakan jaringan internet. Pemerintah Kota Kediri melalui Dinas Kependudukan dan Pencatatan Sipil mengeluarkan pelayanan administrasi kependudukan yang dikembangkan dengan berbasis Sistem Informasi Administrasi Kependudukan (SIAK), mengeluarkan program melalui media aplikasi online yaitu Sistem Administrasi Kependudukan Berbasis Teknologi Informasi (SAKTI). Kota Kediri memiliki fungsi teknologi informasi dan komunikasi yang berperan penting dalam masyarakat dan lebih strategis. Berdasarkan Undang-Undang Nomor 24 Tahun 2013 tentang Pengelolaan Kependudukan. Pelayanan harus dilaksanakan dengan benar dan cepat agar masyarakat puas dengan pelayanan. Berdasarkan uraian tersebut, maka tujuan penelitian ini adalah Mengetahui Pelayanan Publik melalui Aplikasi Sistem Administrasi Kependudukan Berbasis Teknologi Informasi (SAKTI) di Kelurahan Semampir.
\end{abstract}

Kata Kunci: Teknologi Informasi; Pelayanan Administrasi Kependudukan; Kepuasan Masyarakat.

Abstract
Information technology can be done in various ways, one of which is through the internet which
can be used anywhere and anytime using the internet network. The Kediri City Government
through the Department of Population and Civil Registration issued population administration
services which were developed based on the Population Administration Information System
(SIAK), issued programs through online application media, namely the Information Technology-
Based Population Administration System (SAKTI). The city of Kediri has the function of
information and communication technology which plays an important role in society and is more
strategic. Based on Law Number 24 of 2013 concerning Population Management. Services must
be carried out correctly and quickly so that people are satisfied with the service. Based on this
Copyright@2020; Jurnal Mediasosian - pISSN: 2579-342X, elSSN: 2620-5149| 227 
description, the purpose of this research is to find out public services through the application of the Information Technology-Based Population Administration System (SAKTI) in Semampir Village.

Keywords: Information Technology; Population Administration Services; Community Satisfaction.

\section{PENDAHULUAN}

Dalam Undang-Undang Pasal 1 Nomor 25 Tahun 2009 tentang Pelayanan Publik, merupakan kegiatan atau rangkaian kegiatan yang bertujuan untuk menyediakan barang, jasa atau administrasi yang disediakan oleh penyelenggara layanan publik kepada setiap warga negara dan penduduk sesuai dengan ketentuan peraturan perundang-undangan. (Hayat, 2018) mengemukakan bahwa pelayanan publik berhubungan langsung dengan masyarakat sebagai penerima pelayanan. Masyarakat bisa menilai bagaimana pelayanan yang diberikan, pelayanan yang baik akan membuat masyarakat puas, dengan begitu kualitas pelayanan akan semakin meningkat. Peningkatan kualitas pelayanan publik dan kepuasan masyarakat terhadap pelayanan tersebut merupakan tujuan akhir dari reformasi birokrasi pemerintahan. Dalam hal ini kelurahan merupakan wilayah administratif, Kelurahan Semampir berhak memberikan pelayanan yang baik dengan meningkatkan pelayanan melalui kemajuan teknologi informasi dan komunikasi.

Teknologi Informasi bisa di lakukan dengan berbagai cara, salah satunya yaitu melalui internet yang bisa digunakan dimanapun dan kapanpun menggunakan jaringan internet. Dengan begitu mempermudah masyarakat dalam mengakses internet. Pemerintah Kota Kediri melalui Dinas Kependudukan dan Pencatatan Sipil mengeluarkan pelayanan administrasi kependudukan yang dikembangkan dengan berbasis Sistem Informasi Administrasi Kependudukan (SIAK), serta Dinas Kependudukan dan Pencatatan Sipil melalui Sistem Informasi Administrasi Kependudukan (SIAK) mengeluarkan program melalui media aplikasi online yaitu Sistem Administrasi Kependudukan Berbasis Teknologi Informasi (SAKTI) di atur dalam Peraturan Daerah Kota Kediri Nomor 7 Tahun 2015 tentang Penyelenggaraan Administrasi Kependudukan 
dan Peraturan Walikota Kediri Nomor 36 Tahun 2016 Tentang Peraturan Pelaksanaan Peraturan Daerah Kota Kediri Nomor 7 Tahun 2015 Tentang Penyelenggaraan Administrasi Kependudukan.

Pelayanan Publik program SAKTI yang berada ditingkat Kelurahan masih terdapat beberapa kendala, antara lain tingkat sosialisasi, pengetahuan teknis yang kurang memadai, dan banyak masyarakat yang memilih manual daripada berbasis teknologi online. Lain halnya dengan pelayanan yang dilakukan perangkat Kelurahan Semampir yang sudah mampu beradaptasi, mengoperasionalkan dan melakukan pelayanan menggunakan aplikasi SAKTI dengan sangat baik, serta para warga Semampir sudah banyak yang mengetahui adanya aplikasi SAKTI di Kelurahan Semampir. Selain itu sebagai penyelenggara pelayanan publik yang baik, pemerintah menyadari harus tetap menciptakan rasa nyaman dalam penyelenggaraan dalam memberikan pelayanan, yang didasarkan pada Keputusan Menteri Pendayagunaan Aparatur Negara Republik Indonesia Nomor 63/KEP/M.PAN/7/2003, pedoman umum tentang pelaksanaan pelayanan publik. Guna mewujudkan tata kelola yang baik dalam proses pelaksanaannya, pemanfaatan teknologi dan informasi menjadi tuntutan masyarakat. Dalam konteks informasi dan penyebarannya dapat dilakukan dengan cepat dan akurat. Terlebih dari segi geografis Kota Kediri memiliki fungsi teknologi informasi dan komunikasi yang berperan penting dalam masyarakat dan lebih strategis. Berdasarkan Undang-Undang Nomor 24 Tahun 2013 tentang Pengelolaan Kependudukan. Pelayanan harus dilaksanakan dengan benar dan cepat agar masyarakat puas dengan pelayanan. Berdasarkan uraian latar belakang diatas, maka rumusan masalah penelitian ini adalah Kualitas Pelayanan Publik melalui Aplikasi Sistem Administrasi Kependudukan Berbasis Teknologi Informasi (SAKTI) di Kelurahan Semampir.

\section{TINJAUAN PUSTAKA \\ Konsep Pelayanan Publik}

Copyright@2020; Jurnal Mediasosian - pISSN: 2579-342X, elSSN: 2620-5149| 229 
Teori ilmu administrasi negara mengajarkan bahwa pemerintahan negara pada hakikatnya menyelenggarakan dua jenis fungsi utama, yaitu fungsi pengaturan dan fungsi pelayanan. Fungsi pengaturan biasanya dikaitkan dengan hakikat negara modern sebagai suatu negara hukum (legal state), sedangkan fungsi pelayanan dikaitkan dengan hakikat negara sebagai suatu negara kesejahteraan (welfare state). Menurut Kamus Bahasa Indonesia, pelayanan memiliki tiga makna, (1) perihal atau cara melayani; (2) usaha melayani kebutuhan orang lain dengan memperoleh imbalan (uang); (3) kemudahan yang diberikan sehubungan dengan jual beli barang atau jasa.

Secara etimologis, pelayanan berasal dari kata layan yang berarti membantu menyiapkan/mengurus apa-apa yang diperlukan seseorang, kemudian pelayanan dapat diartikan sebagai: perihal/cara melayani; servis/jasa; sehubungan dengan jual beli barang atau jasa, seperti yang dikemukakan oleh (Nawawi, 2012). (Ernanda, 2017) mengemukakan bahwa pelayanan publik adalah kegiatan yang dilakukan oleh seseorang atau sekelompok orang dengan landasan faktor material melalui sistem, prosedur dan metode tertentu dalam usaha memenuhi kepentingan orang lain sesuai dengan haknya. Kegiatan pelayanan publik yang diselenggarakan pemerintah kepada masyarakat meliputi banyak hal yang menyangkut semua kebutuhan masyarakat. (Salsabila Firdausy dan Ummu Nur Hanifah, 2018) menjelaskan bahwa jasa pelayanan pemerintah yaitu berbagai kegiatan yang bertujuan memenuhi kebutuhan masyarakat akan barang-barang dan jasajasa. Jenis pelayanan publik dalam arti jasa-jasa, yaitu seperti pelayanan kesehatan, pelayanan keluarga, pelayanan pendidikan, pelayanan haji, pelayanan pencarian keadilan, dan lain-lain.

\section{Kualitas Pelayanan Publik}

Kata "kualitas" mengandung banyak pengertian, menurut Kamus Bahasa Indonesia, kualitas berarti: (1) tingkat baik buruknya sesuatu; (2) derajat atau taraf (kepandaian, kecakapan, dsb); atau mutu. (Fachruddin, 2018) mengatakan kualitas pelayanan publik merupakan suatu kondisi dinamis yang berhubungan dengan produk, jasa, manusia, proses dan lingkungan dimana penilaian kualitasnya ditentukan pada saat 
terjadinya pemberian pelayanan publik tersebut. Menurut (Salsabila Firdausy dan Ummu Nur Hanifah, 2018) menyatakan bahwa ciri-ciri atau atribut-atribut kualitas pelayanan publik antara lain adalah: (1) Ketepatan waktu pelayanan, yang meliputi waktu tunggu dan waktu proses; (2) Akurasi pelayanan, yang meliputi bebas dari kesalahan; (3) Kesopanan dan keramahan dalam memberikan pelayanan; (4) Kemudahan mendapatkan pelayanan, misalnya banyaknya petugas yang melayani dan banyaknya fasilitas pendukung seperti komputer; (5) Kenyamanan dalam memperoleh pelayanan, berkaitan dengan lokasi, ruang tempat pelayanan, tempat parkir, ketersediaan informasi dan lainlain; (6) Atribut pendukung pelayanan lainnya seperti ruang tunggu ber- AC, kebersihan dan lain-lain.

Untuk dapat menilai sejauh mana kualitas pelayanan publik yang diberikan oleh aparatur pemerintah, perlu ada kriteria yang menunjukkan apakah suatu pelayanan publik yang diberikan dapat dikatakan baik atau buruk, berkualitas atau tidak. (Rukayat, 2018) mengatakan bahwa SERVQUAL merupakan suatu metode yang diturunkan secara empiris yang dapat digunakan oleh organisasi pelayanan untuk meningkatkan kualitas pelayanan. Metode ini meliputi pengembangan pemahaman mengenai kebutuhan layanan yang dirasakan oleh pelanggan. Ini diukur dari persepsi kualitas layanan bagi organisasi yang bersangkutan, kemudian dibandingkan terhadap sebuah organisasi yang "sangat baik." Analisis kesenjangan yang dihasilkan kemudian dapat digunakan sebagai panduan untuk peningkatan kualitas layanan.

\section{METODE PENELITIAN}

Pendekatan penelitian ini menggunakan pendekatan deskriptif kualitatif. Penelitian deskriptif adalah suatu bentuk penelitian yang ditujukan untuk mendeskripsikan fenomena-fenomena yang ada, baik fenomena alamiah maupun fenomena buatan manusia. Fenomena itu dapat berupa bentuk aktivitas, perubahan, karakteristik, hubungan, kesamaan, dan perbedaan antara fenomena yang satu dengan fenomena lainnya (Moleong Lexy, 2000).

Copyright@2020; Jurnal Mediasosian - pISSN: 2579-342X, elSSN: 2620-5149| 231 
Sedangkan penelitian kualitatif berlandaskan pada filsafat metode post positivisme dengan kondisi obyek yang natural. Jadi penelitian kualitatif atau disebut juga penelitian natural atau penelitian alamiah adalah jenis penelitian dengan mengutamakan penekanan pada proses dan makna yang tidak diuji, atau diukur dengan setepat-tepatnya dengan data yang berupa data deskriptif. Pada penelitian ini mendeskripsikan kejadian yang didengar, dirasakan dan dibuat dalam pernyataan naratif atau deskriptif. Jenis penelitian ini berkarakteristik alamiah atau bersetting apa adanya dari fenomena yang terjadi di lapangan yang menitik beratkan pada kualitasnya.

Lokasi penelitian ini ditetapkan di Kelurahan Semampir Kota Kediri Jawa Timur. Peneliti memilih lokasi tersebut dengan pertimbangan bahwa berdasarkan penelitian awal diketahui bahwa pelayanan publik dengan menggunakan aplikasi SAKTI di Kelurahan Semampir sangat membantu masyarakat dalam memperoleh pelayanan, namun demikian ada beberapa warga dari masyarakat Kelurahan Semampir yang belum mengetahui pelaksanaan aplikasi tersebut.

Analisis data kualitatif menurut (Gunawan, 2013) yaitu analisis data adalah upaya yang dilakukan dengan jalan bekerja dengan data, mengorganisasikan data, memilahmilahnya menjadi satuan data yang dapat dikelola, mengintensifkannya, mencari dan menemukan pola, menemukan apa yang penting dan apa yang akan dipelajari, dan memutuskan apa yang dapat diceritakan kepada orang lain. Teknik analisis data yang dipilih dalam penelitian ini adalah model interaktif, dikembangkan oleh (Miles et al., 2014).

\section{HASIL DAN PEMBAHASAN}

Berdasarkan teori yang dikembangkan oleh (Manaf, 2016) bahwa kualitas pelayanan ditentukan oleh lima indikator, yaitu Tangible (terlihat/berwujud), Reliability (kehandalan), Responsiveness (respon/ketanggapan), Assurance (jaminan) dan Empathy (empati). Hasil penelitian terhadap masing-masing indikator dari kualitas pelayanan dapat diuraikan dan dijelaskan sebagai berikut :.

Copyright@2020; Jurnal Mediasosian - pISSN: 2579-342X, elSSN: 2620-5149| 232 


\section{Tangible}

Pada penelitian ini, tangible (terlihat/berwujud) mencakup hal-hal sebagai berikut : penampilan fisik dari perangkat Kelurahan Semampir, fasilitas, peralatan dan sarana komunikasi dan informasi pada pelayanan di Kelurahan Semampir Kota Kediri yang dilaksanakan dalam pelayanan publik kepada seluruh masyarakat Kelurahan Semampir yang membutuhkan pelayanan dalam mengurus surat-surat kependudukan yang sekarang ini secara online. Indikator tangible (terlihat/berwujud) ditentukan oleh yaitu penampilan perangkat Kelurahan Semampir saat melaksanakan tugas, kenyamanan sarana pelayanan, kemudahan memenuhi persyaratan administrasi kependudukan, kedisiplinan perangkat Kelurahan Semampir dalam pelayanan, kemudahan akses menjangkau lokasi pelayanan, dan penggunaan alat bantu komputer dalam pelayanan administrasi kependudukan menggunakan aplikasi Sistem Administrasi Kependudukan Berbasis Teknologi Informasi (SAKTI).

Kualitas pelayanan publik ditinjau dari indikator tangible (terlihat/berwujud) pada Kelurahan Semampir Kota Kediri sudah "sangat baik". Dapat dilihat dari hasil wawancara dengan beberapa perangkat Kelurahan Semampir yakni perangkat Kelurahan Semampir memakai pakaian yang berseragam sesuai jadwal yang ditentukan, sistem kerjanya 5 hari kerja, kedisiplinan pegawai sangat disiplin dengan datang tepat waktu, sarana dan prasarana 90\% lengkap, komunikasi dalam menyampaikan informasi pun baik dan lancar. Dibuktikan juga dengan mendapatnya juara pertama dengan kategori pelayanan terbaik dari Pemerintah Kota dan perkataan dari warga Semampir yang sudah menggunakan pelayanan di Kelurahan Semampir.

\section{Reliability}

Reliability (kehandalan) merupakan kemampuan untuk memberikan pelayanan yang dijanjikan secara cermat, sesuai standar, kemampuan dan keahlian penggunaan alat bantu dalam pelayanan administrasi kependudukan yang dilakukan pada Kelurahan Semampir Kota Kediri. Indikator reliability (kehandalan) ditentukan oleh kecermatan, standar pelayanan, kemampuan menggunakan alat bantu dan keahlian menggunakan alat 
bantu. Tanggapan informan terhadap indikator reliability (kehandalan) berada pada kategori "sangat baik", yang menggambarkan bahwa reliability (kehandalan) dalam rangka kualitas pelayanan publik yang diberikan juga sangat baik.

Kualitas pelayanan publik ditinjau dari indikator reliability (kehandalan) pada Kelurahan Semampir Kota Kediri sudah sangat baik, dilihat dari hasil wawancara yang sudah dilakukan yaitu : petugas pelayanan yang dibantu TI dari DISKOMINFO yang sekarang sudah mahir, sudah cakap menggunakan alat bantu dalam proses pelayanan melalui aplikasi Sistem Administrasi Kependudukan Berbasis Teknologi Informasi (SAKTI), dari kemampuan SDM petugasnya memenuhi kriteria persyaratan dalam bertugas dipelayanan, serta dalam memberikan solusi untuk permasalahan, petugas memberikan arahan yang membuat para pemohon menjadi tahu dan mengerti, seperti misalnya dalam kurangnya surat-surat yang dibutuhkan dalam mengurus administrasi kependudukannya, petugas Kelurahan Semampir memberitahu dan membantu untuk melengkapi surat-surat warga sebagai pemohon yang kurang.

\section{Responsiveness}

Responsiveness (respon/ketanggapan) merupakan kesediaan dan kesadaran untuk merespon setiap pemohon layanan dengan cepat, tepat, cermat, dan merespon setiap keluhan yang disampaikan oleh pemohon administrasi kependudukan. Indikator responsiveness (respon/ketanggapan) dalam penelitian ini ditentukan oleh yaitu merespon setiap pemohon administrasi kependudukan dengan cepat, tepat, cermat, tepat waktu, dan merespon keluhan-keluhan pemohon administrasi kependudukan.

Tanggapan informan terhadap indikator responsiveness (respon/ketanggapan) berada pada kategori "sangat baik" yang menggambarkan bahwa responsiveness (respon/ketanggapan) dalam rangka kualitas pelayanan publik yang diberikan sudah sangat baik.

\section{Assurance}

Assurance (jaminan) merupakan kemampuan aparatur dalam memberikan jaminan, jaminan dari segi ketepatan waktu, biaya, serta legalitas. Indikator assurance 
(jaminan) ditentukan oleh yaitu jaminan tepat waktu, jaminan biaya, dan jaminan legalitas. Tanggapan informan terhadap indikator assurance (jaminan) berada pada kategori "sangat baik", yang menggambarkan bahwa assurance (jaminan) dalam rangka kualitas pelayanan publik yang diberikan juga sangat baik. Kualitas pelayanan publik ditinjau dari indikator assurance (jaminan) pada Kelurahan Semampir Kota Kediri yaitu jaminan kepada masyarakat yang sebagai pemohon itu cepat, tepat waktu, dan selain itu juga 3S Senyum, Salam, Sapa, itu yang paling utama. Diusahakan dalam melayani, para petugas Kelurahan Semampir melakukan dengan semaksimal mungkin untuk memuaskan para warga sebagai pemohon, sehingga dalam melayani petugas Kelurahan Semampir melakukan dengan jaminan yang diberikan yaitu cepat, tepat waktu dan juga berperilaku ramah, dengan menggunakan aplikasi Sistem Administrasi Kependudukan Berbasis Teknologi Informasi (SAKTI) pelayanan jadi semakin lebih cepat, warga sebagai pemohon pun juga senang dan puas.

\section{Empathy}

Empathy (empati) yaitu perhatian yang diberikan kepada pemohon layanan administrasi kependudukan. Kesediaan mendahulukan kepentingan pemohon administrasi kependudukan, sikap ramah, sopan, santun, tidak diskriminatif, dan menghargai setiap pemohon administrasi kependudukan. Indikator empathy (empati) ditentukan oleh yaitu mendahulukan kepentingan pemohon administrasi kependudukan, sikap ramah, sikap sopan santun, dan tidak diskriminatif (membeda-bedakan).

Tanggapan informan terhadap indikator empathy (empati) berada pada kategori "sangat baik", yang menggambarkan bahwa indikator empathy (empati) dalam rangka kualitas pelayanan publik yang diberikan juga sangat baik. Kualitas pelayanan publik ditinjau dari indikator empathy (empati) pada Kelurahan Semampir Kota Kediri jika ada kendala dalam mengurus administrasi kependudukan, pegawai Kelurahan Semampir dengan sigap langsung membantu menyelesaikan masalah tersebut. Karena petugas Kelurahan Semampir prinsipnya membuat masyarakat sebagai pemohon merasa puas 
dengan pelayanan yang dilakukan, serta melakukan pelayanan dengan sebaik mungkin, semaksimal mungkin.

Dengan demikian seperti yang sudah dijelaskan melalui indikator-indikator Tangible (terlihat/ berwujud), Reliability (kehandalan), Responsiveness (respon/ketanggapan), Assurance (jaminan) dan Empathy (empati) oleh Zeithaml dkk. (1990) bahwa Kualitas Pelayanan Publik Melalui Aplikasi Sistem Administrasi Kependudukan Berbasis Teknologi Informasi (SAKTI) di Kelurahan Semampir "sangat baik". Karena dengan adanya aplikasi Sistem Administrasi Kependudukan Berbasis Teknologi Informasi (SAKTI) sangat membantu dalam mengurus administrasi kependudukan dengan sangat bagus dan cepat, yang dulunya manual harus datang ke DISPENDUK langsung dan prosesnya lama, sekarang dengan aplikasi Sistem Administrasi Kependudukan Berbasis Teknologi Informasi (SAKTI) dapat mengurus sendiri atau bisa melalui Kelurahan dengan cara online dan prosesnya pun cepat, 5 hari jadi. Aplikasi Sistem Administrasi Kependudukan Berbasis Teknologi Informasi (SAKTI) adalah program inovasi keluaran DISPENDUKCAPIL Kota Kediri untuk mengurus administrasi kependudukan secara online, cara menggunakannya hanya masuk lewat website dengan memasukkan Nomor Induk Kependudukan (NIK). Adanya pelayanan melalui Aplikasi Sistem Administrasi Kependudukan Berbasis Teknologi Informasi (SAKTI) di Kelurahan Semampir masih ada beberapa warga yang belum mengetahuinya dan banyak warga yang sudah mengetahui. Itu membuat masyarakat merasa puas dengan pelayanan yang semakin baik ini. Kualitas Pelayanan Publik Melalui Aplikasi Sistem Administrasi Kependudukan Berbasis Teknologi Informasi (SAKTI) di Kelurahan Semampir sangat baik terbukti dengan mendapat juara 1 IKM terbaik se-Kota Kediri dari Walikota Kediri pada tahun kemarin.

\section{KESIMPULAN DAN SARAN}

Berdasarkan hasil penelitian sebagaimana dijelaskan pada bab terdahulu, maka dapat disimpulkan :

\section{a. Tangible (terlihat/berwujud)}


Setiap perangkat Kelurahan Semampir memakai seragam yang berseragam rapi. Ketertiban sangat bagus, datang tepat waktu. Kelurahan Semampir menyediakan sarana dan prasarana yang lengkap serta kemampuan komunikasi dan memberikan informasi sangat lancar dan baik, sehingga pegawai Kelurahan Semampir dalam melakukan tugastugasnya dilakukan dengan baik.

\section{b. Reliability (kehandalan)}

Perangkat Kelurahan Semampir mampu menjalankan dan menggunakan sarana dan prasarana secara akurat, mampu memberikan solusi terhadap masalah yang dihadapi dalam melakukan pelayanan yang diberikan kepada pemohon.

\section{c. Responsiveness (respon/ketanggapan)}

Perangkat Kelurahan Semampir sangat tanggap dan cepat dalam menanggapi masalah yang ada, serta proses pelayanan dalam mengurus administrasi kependudukan sangat cepat, karena adanya aplikasi Sistem Administrasi Kependudukan Berbasis Teknologi Informasi (SAKTI).

\section{d. Assurance (jaminan)}

Perangkat Kelurahan Semampir dalam melakukan pelayanan kepada warga sebagai pemohon memberikan kepastian waktu yang tepat sesuai dengan SOPnya yaitu 5 menit selesai, serta pegawai Kelurahan dalam menyampaikan kepada pemohon dilakukan dengan sopan.

\section{e. Empathy (empati)}

Saat terjadi masalah pelayanan dalam melayani pemohon, rasa perhatian pegawai sangat tinggi, karena para pegawai Kelurahan secara sigap langsung membantu sampai menyelesaikan masalah tersebut.

\section{REFERENSI}

Ernanda, R. F. (2017). Pelayanan Publik di Kantor Imigrasi Blitar. Mediasosian, Vol. 1(2), hal. 39-45.

Fachruddin, I. (2018). Strategi Pelayanan Publik di Kantor Kecamatan Kandangan Kabupaten Kediri. Mediasosian, Vol. 2(1), hal. 9-18. 
Gunawan, I. (2013). Metode penelitian kualitatif. Jakarta: Bumi Aksara, 143.

Hayat. (2018). kebijakan publik (R. Tegar (ed.); 1st ed.). Instrans Publlishing.

Manaf, A. (2016). Good Governance dan Pelayanan Publik. Jurnal KPK RI, 1, 58. https://aclc.kpk.go.id/wp-content/uploads/2019/07/Modul-good-governance-aclckpk.pdf

Miles, M. B., Huberman, A. M., \& Saldaña, J. (2014). Qualitative data analysis: A methods sourcebook. Sage publications.

Moleong Lexy, J. (2000). Metodelogi Penelitian Kualitatif. Remaja Posdakarya, Bandung.

Nawawi, J. (2012). Membangun Kepercayaan Dalam Mewujudkan Good Governance. Jurnal Ilmiah Ilmu Pemerintahan, 3(1), 19.

Rukayat, Y. (2018). Kualitas pelayanan publik bidang administrasi kependudukan di kecamatan pasirjambu. Jurnal Ilmiah Magister Administrasi, 11(2).

Salsabila Firdausy dan Ummu Nur Hanifah. (2018). PERMASALAHAN MANAJEMEN KINERJA DI INDONESIA DAN UPAYA KEMENTERIAN PANRB UNTUK MENGATASINYAitle. DEPUTI BIDANG REFORMASI BIROKRASI AKUNTABILITAS APARATUR DAN PENGAWASAN. 